\title{
Formation and Trend of Guanxi Practice and Guanxi Phenomenon
}

\author{
Guoping Jiang ${ }^{1,}$, T. Wing Lo ${ }^{2}$ and Christopher P. Garris ${ }^{1}$ \\ ${ }^{1}$ King Fahd University of Petroleum and Minerals, KFUPM Box 1892, Dhahran 31261, Saudi Arabia \\ ${ }^{2}$ City University of Hong Kong, Hong Kong
}

\begin{abstract}
With the increase of interactions between Chinese and international communities, guanxi, a Chinese term, has catching more and more attentions from non-Chinese speaking people. Guanxi, from a sociological perspective, is formed on the ascribed, social or third party bases through the mechanism of ganqing and renqing. Different from other scholars, the authors consider guanxi phenomenon is an outcome of co-impacts from Confucianism and institutionalization of material factors and structural factors. It is argued that guanxi phenomenon will decline in future China gradually because of rationalization required by capitalism but will not disappear completely due to human nature and cultural nature.
\end{abstract}

Keywords: Guanxi practice, guanxi phenomenon, institutionalization.

\section{INTRODUCTION}

Guanxi (pronounced "gwan-shee") is often associated with corruption, as such, it can be viewed as having existed in Chinese society for thousands years. However, guanxi, as it exists in everyday life, is a modern Chinese term. Loosely translated as "connections," it is a relatively recent Chinese word to gain entry into the English vernacular. While the term was virtually unknown to non-Chinese speakers a decade ago, it is used by Chinese and non-Chinese speakers alike today, and it has made its way into many academic arenas.

Guanxi is a cultural characteristic that has strong implications for interpersonal and inter-organizational behaviors in Chinese society (Pye 1995). In China, people as well as organizations try to nurture guanxi energetically and subtly, which influences their attitudes toward long term social and personal relationships (Sik 1994). Guanxi is a complex social act, and as such, is difficult to easily define. Scholarly descriptions of guanxi include "tight, close-knit networks" (Yeung and Tung 1996), "interpersonal connections" (Xin and Pearce 1996; Leung et al. 1996), a "gate or pass" (Yeung and Tung 1996), "particularistic ties" (Jocobs 1979), "friendship" (Pye 1982), and "reciprocal exchange" (Hwang 1987). According to Bian (1994), guanxi could refer to one of three things: (a) the existence of a relationship between people who share a group status or are related to a common person, (b) actual connections with and frequent contact between people, and (c) a contact person with little direct interaction. Apparently, the term is loosely defined in

*Address corresponding to this author at the KFUPM Box 1892, Dhahran 31261, Saudi Arabia; Tel: 00966+3+8607411; E-mail: Jiang@kfupm.edu.sa the Chinese language, as it takes on multiple meanings, again not lending itself to a simple translation. This is why Tsui and Farh (1997: 59) remark, "the literature (both Chinese and English) shows no consensus in the translation or definition of term guanxi". All these definitions are useful as they depict guanxi as a kind of personal relationship, however, relationships do not necessarily produce guanxi. In this paper, Guanxi is defined as the embodiment of an institutionalized behavioral pattern on interpersonal relationships involved with human affective components and human obligations under Confucianism and an institutional structure.

There are both areas of theoretical and empirical research on guanxi, but most papers tackle guanxi from a business management perspective (e.g Chen and Chen 2004; Gu, Hung and Tse 2008; Lee and Dawes 2005, Lin and Si 2010; Wong 2010). Thus far, there has been no sufficient academic review addressing the bases and mechanisms of guanxi and the trend of guanxi phenomenon in China from a sociological perspective. This paper provides a sociological analysis of such issues.

\section{THE FORMATION OF GUANXI PRACTICE: A MICRO VIEW}

\section{Guanxi Bases}

In China, guanxi usually starts with a "guanxi base" (Tsang 1998), either from a blood relationship or social interconnections. According to Jacobs (1979), a commonality of shared attributes, identity, or origin serves as the base of guanxi. The guanxi base can be categorized into three groups: ascribed bases, social bases, and third party bases. 
An ascribed base refers to pre-existing qualities, inherited at birth, for example, locality, kinship, surname, and dialect (Fried 1974; Luo 1997; Skinner 1977). The nature of some shared attributes could be quite variable in that they can be changed depending on social shifts across time. For instance, locality can mean a small village, a county, a city, a province, or even a regional grouping of provinces. Even kinship (or family) can be stretched from a core family membership to a distant family only remotely connected to someone (e.g., distant relatives) (Rosemont 1991). The elasticity of these bases of guanxi gives Chinese people different social resources and various approaches to establish a web of personal relationships.

Social bases refer to relationship between colleagues, classmates/alumni, student/teacher, and other social associations (Ambler 1994). The guanxi arising from these bases usually happen outside of the family. Some social bases must be achieved, while others are inherently provided. For example, you can choose to be a member of friendly or professional associations, but you cannot choose your classmates or coworkers.

The third party base is necessary when one or both of the individuals want to establish guanxi, but do not have any shared identities. Not every set of people fit into the general ascribed and social guanxi bases. If no base exists and favor is in need, the involved parties often seek a third, fourth or even fifth party to establish guanxi. Such a process is called "seeking guanxi" (Kipnis 1997). It becomes more and more common in the highly mobile Chinese society (Kundu 2000), since guanxi based on ascribed and social bases are always not available due to the mobility.

Therefore, the amount in which people can cultivate guanxi around them depends upon their positioning in a social structure which is based on social unit classification, such as family, work units, and/or social network. The more attributes people possess, the more guanxi they potentially have, if they have an intention of guanxi-building and would like to navigate through this potential guanxi web (Leung, Heung and Wong 2008). However, it should be noted that the existence of a basis for guanxi does not guarantee such an alliance, but has the possibility to do so. For example, a person may have many relatives (close or distant), but he only has guanxi with the ones with which he interacts; the guanxi with other relatives are not activated therefore won't affect much. Therefore, the existence of a base does not equal guanxi, but paves the way for a chance to build up guanxi (Fan 2002). Relatively speaking, it is much easier to establish guanxi with a pre-existing guanxi base. If a shared guanxi base cannot be located, one may have to rely on intermediaries (i.e. a third party base) who have guanxi bases in common with both himself and the desired contact. This illustrates the importance of personal recommendations.

\section{Mechanisms of Establishing Guanxi}

An existing guanxi base alone is insufficient to build up strong guanxi. The individuals must interact, exchange favors, build trust and credibility, and work over time to establish and maintain the relationship. Usually, Chinese individuals, based on shared identity, establish guanxi in two ways (i.e. based upon two different mechanisms), which are ganqing and renqing (Kipnis 1997; Huang 2002).

The ganqing is a Chinese concept without a precise English equivalent. Translations of "sentient", "feeling", and "emotions" are prevalent, but inadequate; therefore, we shall simply state that ganqing is the "affective component" of guanxi (DeGlopper 1978:318) and use this original term. To build guanxi, a guanxi base is not enough. There is a need for ganqing, which is a measure of its relative "usefulness" or the extent of the emotional commitment and psychological dependency (Tsui and Farh 1997). It is the emotional nature of guanxi that tends to tie people together, and this includes a commonly understood commitment to aid in the realization of one's interest. For guanxi within extended families or between relatives, ganqing is always the way in which guanxi is built, because ganqing exists inherently in this social circle. For nonkinship connections, if one wants to establish guanxi through ganqing, the experience of sharing and interaction through living, (e.g. working or studying together) is a prerequisite. It may happen that two people have a guanxi base, but no ganqing, and thus no guanxi is cultivated. Ganqing varies in warmth and intensity and may be improved over time. It may be described as "strong" or "weak" alluding to its depth of feeling and one's willingness to sacrifice personal interest to assist a guanxi member (Kipnis 1996).

Renqing is another avenue for building guanxi, and is much different from ganqing. Yang (1957:292) equaled renqing to "human feelings," and said, "[Renqing] covers not only sentiment but also its social expressions such as the offering of congratulations or 
condolences or the making on appropriate occasions. But, Silin's (1970: 43) translation of "human obligations" is probably closer to the meaning of renqing. In his opinion, renqing can be interpreted as the unspoken norms of Chinese interpersonal relationships. It grows out of Confucian norms of interpersonal relationships, one of which is the concept of Shu, or reciprocity, a value that Weber treats as the foundation of Confucian social ethics (Silin 1970:162). Weakland (1950:364) also stated: "The system of reciprocal aid in Chinese life .... is centered around the concept of "renqing"'. Guanxi is possibly established when one party helps another party (either symbolic or substantive), particularly when the obligation is not paid off. Because of the norm of reciprocity, this unpaid obligation, or renqing, will lead to a series of exchanges, which ultimately results in the formation of a guanxi-based relationship.

In short, guanxi based on kinship usually starts from ganqing while other kinds of guanxi typically start from renqing. However, as time passes, both kinds of guanxi contain both ganqing and renqing components. The only distinction is the proportions of ganqing and renqing in guanxi. For example, business guanxi usually has less ganqing elements than other guanxi.

\section{Conditioning Factors}

The first factor is face. Having a guanxi base and building ganqing or renqing still cannot guarantee close guanxi. Other conditioning factors also play a role in the guanxi building process. Face is one such factor. As Goffman (1955:213) defined, face is "the positive social value a person effectively claims for himself by the line others assume he has taken during a particular contact." Face, as the successful presentation of trait, is one's situated identity. In any encounter, failing to have one's identity ratified means losing face; on the contrary, having one's identity ratified means having face. Saving face means that you have to maintain an identity from being challenged at the moment. Therefore, face isn't something that resides within an individual, but rather within the flow of social situational events. The centrality of face's role in Chinese society can be attested by the outpouring of literature addressing the topic (Hu 1944; Yang 1955; Jacobs 1979; Hwang 1987; Jankowiak 1993; Smart 1993; Yang 1994; Kipnis 1995). Indeed, face is a key element in the development and maintenance of guanxi. A person can take control of dynamics in social networking as long as strong face is obtained (Lin 2010). It is thus valued by Chinese so as to promote guanxi (Earley 1997). If a person wants to build up or maintain guanxi with another person, s/he has to protect that person's face. This may entail behaviors like drinking a toast to someone, accepting an invitation, honoring someone's help or offering him/her help. If you protected a person's face, you would earn a special credit (symbolic capital in Bourdieu's sense) which can attract other forms of capital for yourself.

Though highly abstract, the concept of face is interpreted and used in a quantifiable and measurable way by the Chinese (Luo 1997). How much face an individual has depends on the size of his/her guanxi network and the powerfulness of his relationships. Usually, the larger one's guanxi network is, or the more powerful one's connections are, the more face one has. Also, giving favors to the weaker noticeably demonstrates his/her power or capacity beyond common peers, thus gaining face. As mentioned earlier, the norm of Chinese reciprocity provides that people who have received help should be thankful and willing to return the favor whenever called upon or necessary. Disregarding this expected reciprocity can make the party previously that helped lose face and also seriously damage this party's own social reputation (Hwang 1987). Sometimes, a certain amount of face is need to cultivate a viable guanxi network (Hwang 1987), particularly when a person is from a network of lower status. In short, in the process of guanxi-building, both parties should be cognizant of face. Without adequate and positive face, all previous efforts may be wasted.

The second influential factor is trust. Since guanxi is a long-term relationship, it is always of significance for the parties involved to "read" trustworthiness from each other. The Chinese find it very difficult to establish relationships when there is no trust built. Guanxibuilding can be seen as trust-building because trust promotes a willingness to rely on a party and to take risks (Morgan and Hunt 1994). Therefore, Chinese tend to work at creating trust beforehand (Wank 2001). Generally, the higher the level of trust between involved parties, the greater the probability of a longterm relationship. Guanxi engaged in opportunistic behaviors (i.e. low trust) is easily discontinued (Lee 2010).

\section{Characteristics of Guanxi}

The first feature is reciprocity. The norm of reciprocity is universal (Brown 1991; Jensen 1997; Wong 1997). Nevertheless, in China the principle is 
marked by a high degree of consciousness as well as its tremendous influence in social institutions. Such an influence can be seen from an old Chinese idiom, "a drop of favor received, repay in pour." Directed by this ethical code, Chinese have a strong sense of reciprocity for the sake of developing guanxi and saving face for themselves as well. Given this code, Chinese are ready to do others favors for the sake of potential guanxi or establishing face in the typical Chinese society. Unfollowing the principle of reciprocity and refusal of returning a favor will certainly result in a person being viewed as untrustworthy (Alston 1989). Different from Western reciprocity, Chinese don't encourage immediate discharge of reciprocity (Lin 2010), because it may give him/her an impression that you don't want to keep guanxi (i.e. the debt is paid off, not owing you). The rules of reciprocity in guanxi act as a structural constraint that represses self-seeking opportunism which is viewed as short-sighted. It also helps preserve social capital within the existing network structure (Coleman 1990).

Utilitarianism is the second feature. Guanxi is a mixture of ganqing and renqing, no matter what kind of guanxi. In some cases, ganqing takes a large part while in others renqing takes a larger part. The ganqing (sentiments) and renqing (favors) bond two persons together. Therefore we can see that, more or less, guanxi is unethical because it "helps" individuals to prevail, by calling on others for a favor or service (Wong 2010). It is hard to imagine that guanxi relations that are no longer profitable or not based on mutual exchange can be kept for a long term (Vogel 1965). Returns are always encouraged when the involved parties are complementary in skills, resources and social capital, and both parties need each other, temporarily or strategically.

Transferability comes third. As mentioned earlier, the use of a third party that will vouch for one's reliability is a more effective technique than personally initiated efforts to establish contacts because guanxi has the connotation of "familiarity", which implies builtin trust (Wellman and Wortley 1989). The extent of the transferability of guanxi from direct to indirect contacts depends upon the strength of the ties between parties. If party $A$ has strong guanxi with $B$, and $B$ has heavy relationship with $C$, then it is very possible for the party $A$ and $C$ to set up guanxi.

The last characteristic is intangibility. The same as western relationships, parties should be committed to each other in guanxi if they want to keep a long term guanxi. However, the commitment or reciprocity is followed intangibly. You may want to establish guanxi with one person, but you may never want to ask "may we have guanxi". You can feel the existence of guanxi but you cannot measure or touch it physically. Although guanxi doesn't specify the range or frequency of exchanging favors, people who share guanxi are still supposed to be committed to one another by an invisible and unwritten code of reciprocity and equity (Luo 2007; Yan 1996). Otherwise it may break guanxi or at least weaken guanxi.

The above micro analysis of guanxi can be summarized with the Figure 1.

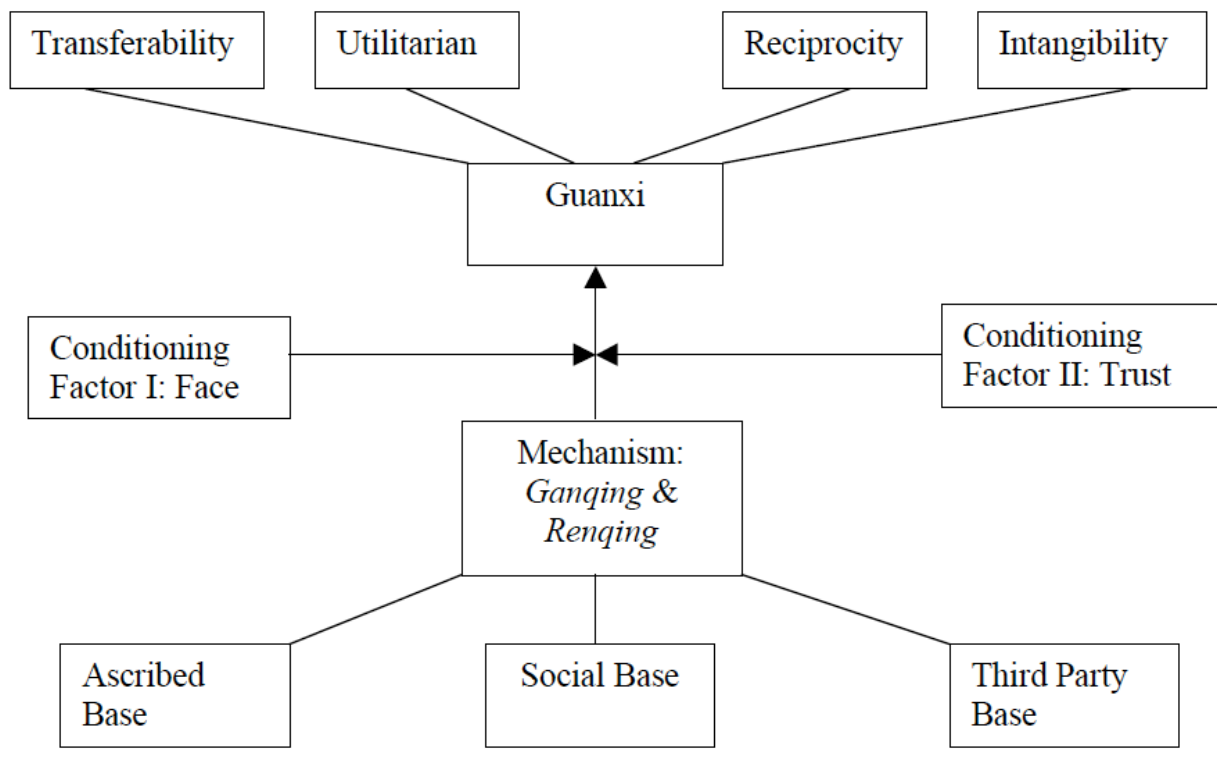

Figure 1: Formation and characteristics of guanxi. 


\section{FORMATION OF GUANXI PHENOMENON: A MACRO VIEW}

Guanxi practice is not unique to a small Chinese group or community. In contrast, it has been a social phenomenon widely existing in Chinese society for more than two thousand years although the term was recently coined and used by academia. Its existence is the outcome of long standing social culture and social institutions.

\section{Cultural Factor}

Guanxi is a particular phenomenon deeply rooted in Chinese Confucian culture that gradually developed throughout Chinese societies. Confucianism, as the Chinese ethical and philosophical system, treats social harmony as a great life goal for everybody. The harmony is believed to be able to bring businessmen money or make family prosper (Liu 2003). Guanxi can be traced back to an origin in Confucianism which is characterized as "relation centered" or "social oriented" (Hwang 1987:945; Yang 1981:159). According to Confucianism, an individual is fundamentally a social or relational being rather than a discrete or isolated being. Social harmony for Confucianism can only be achieved in the context of interaction among individuals (Boisot and Child 1996). In other words, social order and stability can be reached through properly differentiated role relationships and harmonious interactions among them (King 1991). For instance, a citizen must be loyal to the government, and a son must be loyal to his father. If all follow the rule of role relationship, the consequence, no doubt, will be social harmony.

Under such a heavy influence of Confucianism, Chinese often view themselves interdependently with components of surrounding social environments, and it is this self-in-relation-to-others that influences the individual's experience. This view of an interdependent or relational self is dramatically divergent from the Western view of an independent self (Ching 1977). In Chinese society, the self is identified, recognized, and evaluated in terms of one's relations to the groups and communities to which s/he belongs to ( $\mathrm{Li}$ 1993). In a relation-centered world, social relations are ascribed greater significance, and relationships are often seen as ends in and of themselves rather than being means for realizing various individual goals. Due to such emphasis on differentiated relationships, Chinese pay more attention to attachment, harmony, and long term relationships than many other cultures (Hui and Triandis 1986). This is most salient in the interaction of in-group members. Scholars from various fields (e.g. Butterfield 1983; Parsons 1949) noticed that the Chinese are more likely to divide people into groups and treat them accordingly compared to western societies. Such an inclination of treating people differently dependent upon the relationships with him/her may explain most why guanxi is of such importance in Chinese societies.

\section{Material Factor}

Although China is one of four ancient civilizations, the basic needs were not always fully satisfied for all Chinese due to continuous wars, famine, and natural disasters. Moreover, most goods were bureaucratically or unequally distributed in traditional Chinese society (Baldinger 1998). Under these conditions, connections were vital for Chinese to survive. The scarcity and unequal distribution of resources made ancient Chinese people rely on instrumental personal relations, which is based on guanxi to accomplish tasks (Su, Mitchell and Sirgy 2007). This led to a lack of respect for law, regulations, and for the concept of everyone being equally subject to universal standards of law and morality. Lin and Si (2010), through empirical studies, showed that strong ties are associated to resource scarcity. Fermented by Confucianism, such kinds of behaviors grew rapidly in China. And this tradition has been kept alive. Currently, guanxi with bureaucrats is still a very beneficial means of receiving preferential treatments as they may follow the policy of "opening one eye and closing the other," but avoiding bribery and corruption (Lo and Jiang 2006; Yang 1986). In the economic field, businessmen may rely on industrial supply agents who have a guanxi network to access limited resource such as coal, glass, gasoline, cement, or lumber.

\section{Structural Factors}

The formation of the widespread guanxi phenomenon is also an outcome of an institutionalization process that brought a gradual growth and crystallization of guanxi in various social and organizational settings.

The first factor is a weak legal system. Historically in the Chinese agrarian society, the emperor was the issuer and interpreter of law. In a sense, we can say there was no law in feudal China other than emperors (Chen 1973). The pre-reform China (1949-1978) was a socialist state that adopted the Marxist theory which holds that law is an offensive instrument employed by 
capitalists against the working class. Therefore the government effectively dismantled the legal system and replaced the legal court with the people's court. People's police, people's court and procuratorate were even abolished in the Cultural Revolution and replaced with Security Department at all levels (Chen 2008). Law enforcement staffs (police, judge and procurator) were selected on their political reliability and proletarian class background. The post-reform China (1978-now) recovered the legal system gradually, however, even in post-reform China, the rules, regulations, and policies are open to interpretation by those who occupy positions of authority or power (Cohen, Edwards and Chen 1980). Consequently, whereas western nations depend on contractual law, Chinese use personal contracts and negotiation to resolve disputes in various eras. Social institutions made them believe that a guanxi approach is a much more effective and efficient way to resolve fights and disputes than the judicial system (Kim 1981). The legal system functioned ineffectively, as did other social institutions.

The second is the presence of irrational political system. Nepotism has long been a characteristic of Chinese politics, no matter in agrarian society or in modern society (Ren 2008). Frequently, nepotism meets the problem of self-control (Chiu 1995). Insufficient self-control leaves many structural holes where guanxi can play a role. An illustration for this is that officials' interpretations guide the enforcement of policy. The popularity of guanxi in Chinese politics is also rooted in the fact that guanxi provides an informal mechanism to circumvent the cumbersome Chinese bureaucratic rules. In other words, while the Chinese bureaucracy often inhibits action, guanxi facilitates it (Alston 1989).

The third factor is the irrational economic system. During the centralization periods (1949-1978), Chinese government, through the agency of the state apparatus, made national and regional plans and set production targets, wages, and prices throughout the country (Baldinger 1998). The distribution of basic foods and certain consumer goods were coordinated by its system of rationing. Under the centralized state redistributive economy, many other aspects of social economy such as labor assignments, housing allocation, and the regulation of population migration were controlled by Chinese government and its agency (Greaves and Baldwin 1994). The centralized economy also addressed the process of social reproduction, thus controlling marriage, divorce, and birth in the population, as well as medicine, education, the media, and the arts (Holmgen 1995). Given this, guanxi turned out to be indispensable to gain access to distribution channels which were controlled by the state officials under a planned economy. Apparently, the nature and pattern of a Chinese planned economy stimulated pervasive guanxi-based connections in pre-reform China. The post-reform Chinese economy is characterized by an undeveloped market structure, relatively poorly specified property rights, and institutional instability, which makes market exchanges uncertain and costly (Nee 1992). This temporary situation resulted in a heightened interest of the people in opportunistic behavior and higher transaction costs. For instance, through a research on job market, Bian (2002) found that there were various structural holes in China making formal channels ineffective for transmitting information, building trust, and binding obligation between job seekers and prospective employers.

In a nutshell, Confucianism instills relation-centered code in the Chinese mind. At the same time, the institutional instability, structural inefficiency, and limited social resource led Chinese to cultivate guanxi to substitute for reliable governmental and institutional support which is always labeled "structural support" (Coleman 1993; Fallers 1965; Putman 1993, Walder 1986). When these two meet (Confucian code and the specific Chinese societal structure), a wide-spread and long lasting guanxi phenomenon formed. Once guanxi phenomenon emerged in China, it reversely played a role in the persistence of Confucianism, and indirectly helped itself prevail in Chinese society. Accordingly, guanxi phenomenon is not a recent or new Chinese phenomenon; it has been a part of Chinese society with different names for two thousand years, far away Yang's argument (1994) that guanxi phenomenon emerged during the Cultural Revolution in 1970s.

The above argument can be illustrated with the Figure 2.

\section{THE TREND OF THE GUANXI PHENOMENON}

In 1978, China started an economic reform which transformed a centrally planned economy into a market driven economy (Bian 1994; Walder 1986; Schell 1989). So far, the market in China has been expanded to most economic fields, including education and medical care. More precisely, China is on the road to capitalism (Glassman 1991; LaBaron and Donna 2002). The capitalist system had very influential impacts on guanxi phenomenon. The impacts of 


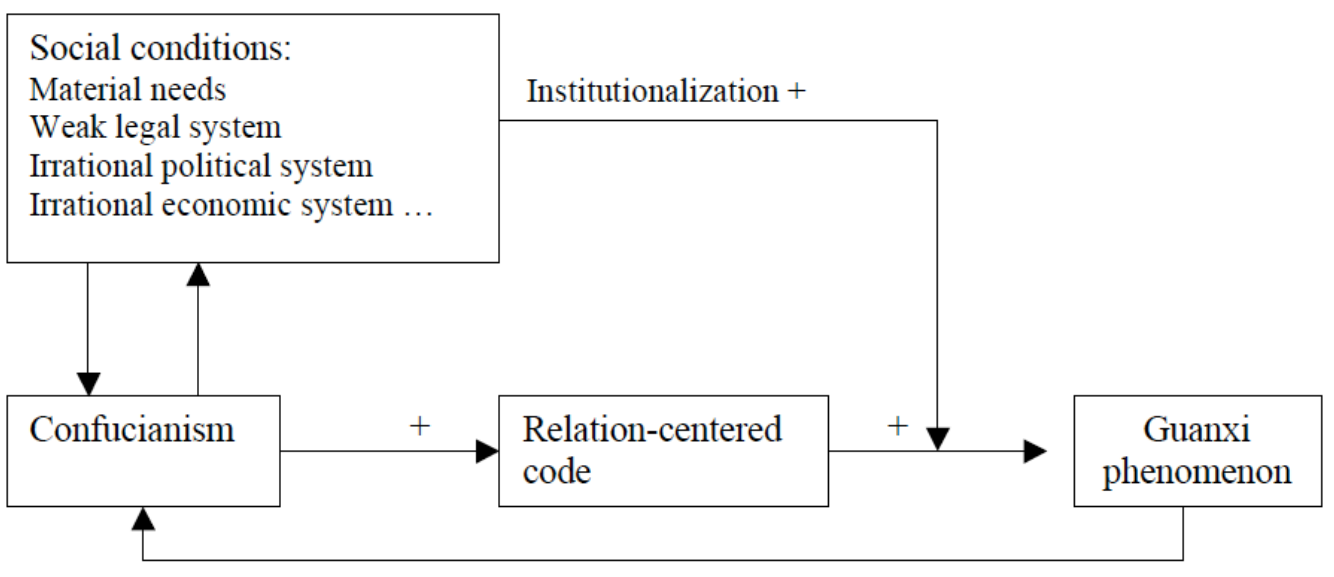

Persistence and modification

Figure 2: The formation of guanxi phenomenon.

capitalism on guanxi phenomenon were made through two ways which are the spirit of capitalism and mechanism of market. First, the spirit of capitalism is pursuit of forever-renewable profit via rationality (Weber 1997). Modern capitalism is defined by "the rational (deliberate and systematic) pursuit of profit through the rational (systematic and calculable) organization of labor and through rational (impersonal and purely instrumental) exchange on the market guided by rational (exact, purely quantitative) accounting procedures and guaranteed by rational (rule-governed predictable) legal and political system" (Weber 1978:225). Needlessly to say, for Weber, the essence of modern capitalism is rationality. How to reach rationality? The only answer, according to Weber, is rationalization. Therefore, the economic reform actually means rationalization to China. To make capitalism successful, China has to go through rationalization similar to that of Western countries. According to Weber, rationalization involves "the depersonalization of social relationship, the refinement of techniques of calculation, the enhancement of the social importance of specialized knowledge, and the extension of technically rational control over both natural and social process" (Brubaker 1984:2). To reach such kind of rationality, Chinese government made numerous institutional changes. Individuals also change in accordance with the rationality requirement so as to be successful. Obviously it puts guanxi in a different social environment, or more precisely, in a smaller space. Consequently, guanxi practice is being reduced; thus the significance of guanxi is also declining. Second, the capitalism is run through the mechanism of market, or to say the profit is obtained through market. Market means individuals-oriented competitions which impede nepotism, favoritism and guanxi. In this sense, again, guanxi phenomenon will wane in China. It is far away from Yang (1986) and Bian's $(1994,2002)$ argument that guanxi will be more pervasive in the future of China in that there are the following changes which more or less will influence Chinese people's behavior.

\section{A More Complete Legal and Regulation System}

Influenced by the Western business, Chinese government has put much effort in legislation construction after 1978. Over the last 40 years, 946 laws have been passed by Chinese National People's Congress (State Council Information Office 2011). The number of lawyers has surpassed 166,000 by 2009 (Ministry of Justice 2010). Law is gaining more and more attention in people's lives. By the 1990s, the rational legal structures constructed at the state level have begun to have tremendous regulatory strength, and have begun shaping the ways in which individuals act in social and economic spheres, particularly after China joined the World Trade Organization (Harvie 2000; Hutchings and Weir 2006). For instance, government functionaries must have bachelor's degree and must pass the Civil Services Examination; construction companies must meet particular qualification standards if they want to bid a project; governments only buy commodities from companies whose products passed certain quality check; bank won't lend customers a loan if $\mathrm{s} /$ he doesn't meet basic requirement such as stable income and mortgage. As these legal and institutional changes are taken more seriously in society, economic actors alter their behaviors accordingly, especially those large and powerful actors in the industrial economy that are being overlooked by government. They may be more likely to take official institutional changes seriously. This has not only happened in the economic field, but also in the 
social field. More and more people are relying on law to resolve problems, which had been done by guanxi before the Reform due to the absence of law (Turner, Feinerman and Guy 2000). This impact will become more salient when a more complete Chinese legislation system emerges.

\section{Decentralization in Administration}

In the domain of administration, bureaucracy is adopted to fulfill rationalization. However, bureaucracy entails dehumanization: it requires the complete "elimination [of] love, hatred, and all purely personal, irrational, and emotional elements which escape calculation for official business" (Weber 1978). This process in China is associated with decentralization. Since 1979, the Chinese reform has expanded the role of market in allocating social resources such as housing, education, medicine, labor, etc (Woo 1999). Chinese Officials don't have complete control over the distribution of resource and products anymore. Let's take job-seeking as an example. In current China, passing a vocational exam is usually a common prerequisite of job recruitment (Wang 1996). Interviews sometimes follow the examinations. In the first round, guanxi is stopped, although it cannot be blocked entirely. If one cannot pass the exam, he/she cannot get to the second stage unless he/she has strong guanxi. In short, universal standards and universalistic ethics are being established in China, and tremendous progresses have been made. These changes have been moving Chinese focus from guanxi to rationality.

\section{Competitiveness Embedded in Market}

Various scholars (Chang and Evans 2000; Rodrik 2000; Stiglitz and Meier 2000) emphatically point out that a market system needs good physical, legal and social infrastructure to guide and regulate it. A competitive atmosphere is one of them. As the economic transition progresses, markets in post-reform China are becoming increasingly competitive. This has forced economic actors to make their decisions on the basis of assessment of economic factors (price, quality, efficacy, etc.) rather than social relations (Gu, Hung and Tse 2008). Further, the self-responsibility policies and other aspects of hardening budget constraints have made companies and individuals aware of that they cannot count on the state to bail them out (Whiting 2001). Therefore, there are very real economic incentives and constraints against favoring social connections over the economic principle of the quality and price in post-reform China. As a result, guanxi will not be treated paramountly.

\section{Individualization}

The development of modern capitalism also presupposes a rationalization of the personality (Parsons 1958). The feature of such a rationalized personality is an emphasis on individualism and selfreliance (Erez and Early 1993; Triandis 1995). Chinese, after 1949, were organized politically into rural and urban collectives. Plus the traditional (culturally) linkages among individuals such as family, kinship organization, and local community, they were more collective than before. It was so collective that Chinese lost some freedom and autonomy. However, along with the introduction of a restructured market, individualism was also introduced to China either by institutional changes or by communication with the West. First, the institutional linkage between Chinese individuals and Chinese government were broken gradually after the Reform and Open Policy in 1978. For example, Chinese government abandoned many previous provisions and responsibilities encouraging self-reliance; Ideological loosening reduced the sacrifice of individual interests for benefits of nationstate. Job mobility, once greatly restricted, is now common due to dismantling of the "iron rice bowl" (permanent job). One estimate indicated that $15 \%$ of Shanghai workforce changed jobs in 1993, almost 10 times the prior rate (Tsang 1998). It is predicted to be much higher nowadays. As people are in higher mobility, it is presumably harder to maintain the ties that lead to strong guanxi. In a word, Chinese government has been playing a less important role in their lives since then because of privatization of labor, education, medical care, housing, migration, and marketization (Yan 2010). Second, the more open China is, the more western culture including individualism Chinese absorb. Right now, western cultural products including movies, TV programs, and books have entered Chinese markets successfully. Simultaneously, millions of Chinese travel or study abroad every year. What they learn, see and experience in the West has an impact on their life back in China. Consequently, individualization emerged and grew rapidly in the post - Mao China. Scholars have observed such changes in Chinese people's values and attitudes (e.g. Ralton et al. 1995; Yang 1986, 1988). For instance, Yang $(1986,1988)$ found that the more modernized Chinese tend to have a stronger motive for individual-oriented achievement, equality, exhibition, and autonomy. Recently, Hansen and Pang 
(2008) discovered that in the rural area, Chinese rural youth have developed a strong sense of individual responsibility for success and failure and even tried to idealize individual choice on the base of concept of freedom, free love, independence, and personal development. Such an individualist trend definitely erodes the base of guanxi in contemporary China. As a result, we can expect that modern Chinese people will identify less with family and more with other social groups than traditional Chinese people. Given this, identification will be more important and obligation will be less important in the modern Chinese's work relationships. This social transition works an alternative to traditional Chinese values, which is referred to as individual modernity (Inkeles and Smith 1974). It partially backs up Beck and Beck-Gernsheim's (2002) argument of the overlap of globalization and individualization.

\section{Internal Cultural Counterforce}

Admittedly, in the Confucian relation-based social system, the focus is on the particular nature of the relation among individuals. However, as De Bary correctly notes, "the relations alone ..... do not define a man totally. His interior self exists at the center of this web and there enjoys its own freedom" (1970:149). In the relation establishment process, it is the individual who finally defines roles for himself/herself and others, and is always at the center (Fei 1967). Just because of this voluntaristic nature, guanxi is oppressed by individuals in many cases.

\section{Other Influences}

Other changes in post-reform China also affect the practice of guanxi. The increase of information flow through the internet and various telecommunications also weigh against the traditional forms of relationships as people have more direct sources of information and influence (Foster 2000). Guanxi practice, consequently, faces a less solid base in the post-reform China than pre-reform China.

Overall, contemporary China is experiencing rationalization to meet basic requirement of capitalism. The implemented institutional changes render it difficult for people to use personal power and relations to accomplish private, procedural and official tasks. Also, the nature of market (competitiveness), job mobility, the quick flow of information, and an internal cultural counterforce are narrowing guanxi into a smaller space. This process is illustrated in the Figure 3.

However, contrary to what Guthrie (1998) argues that guanxi will fade out completely as capitalism grows in China, it will persist because guanxi has long been a part of Chinese culture. First, the above transitions are complex because these changes are taking place on top of an institutional system, which over 2,000 years of history has made guanxi routine in Chinese society.

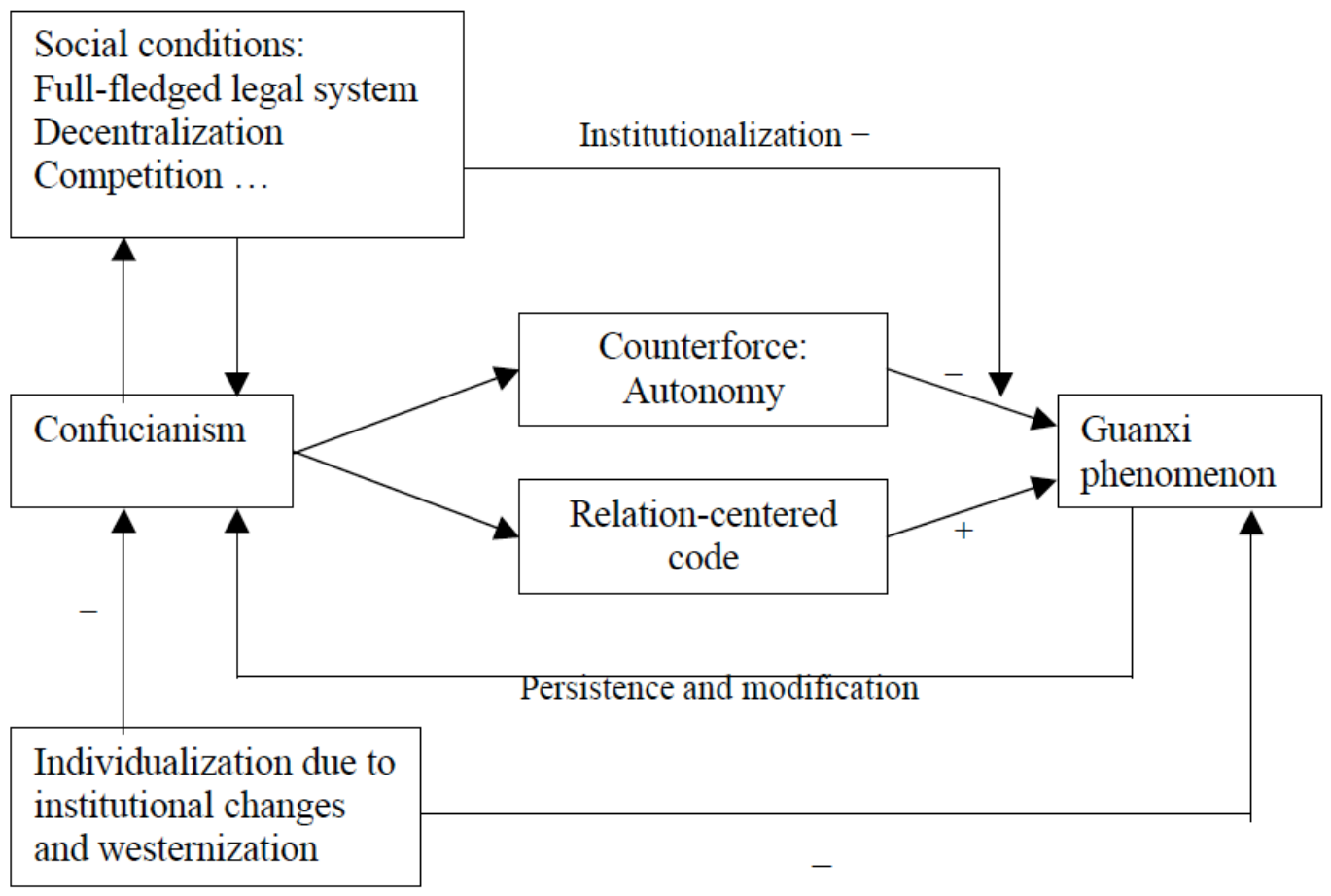

Figure 3: The fading of guanxi phenomenon 
Second, a legalistic culture runs much deeper than the single construction of law. Instilling an understanding in the Chinese mind that the law and market are important in their daily lives has a long way to go. This kind of transition is always an incremental and gradual process that will occur over a significant period time. Third, that the market is run by demand and supply is ideal. Government always has a hand in the market, so there is nexus between Chinese party-state and businessman. That is why Chinese economic system is called state capitalism which is always linked to crony capitalism. Informal political agency (guanxi) is constantly developed to bridge them (Delman and Yin 2008). The nexus between businessman and businessman is also mediated by guanxi for the reason of trust, and affection. The new term "guanxi capitalism" was even invented to describe the penetration of guanxi network into governmentbusiness and business-business relations. Various studies even verified the positive function of guanxi in businesses (Hsu 2005; McNally 2011; Ruehle 2010; Zhao 2005). Fourth, some of the most important Chinese traditional attitudes, beliefs, norms, and values (such as that of family) carry on and are unlikely to be substituted by modern ones in the near future, that is why Hansen and Pang (2008) found in their research that the family still remains the most important collective emotionally and in terms of social security and support although individualism is rampant in the Chinese countryside. Fifth, as an institutionalized behavior pattern backed up by core Chinese values for thousands years, guanxi has been taken for granted, neutralized or excused even if there is a negative feedback on it. Or to say it has been a part of Chinese culture which changes gradually only unless there is a powerful external influence. Therefore the aforementioned factors determine that although guanxi is becoming less and less important to Chinese people, but it will stay in Chinese society for a long time. The transition will be a slow and incremental process, and it perhaps can never be cleaned out in Chinese communities just like social network still exists in Western societies. After all, even in Western societies, there is a common saying that "who you know is more important than what you know" (Ma 2011).

\section{DISCUSSION}

Guanxi is particular to China, but, the guanxi phenomenon is common all round the world. Russia, Japan, Korea, Haiti and Arab countries have similar dynamics (Larson and Kleiner 1992; Cunningham and Sarayrah 1994; Mintz 1961; Ledneva 1998).
Japan is known as "the network state", and most Japanese people have a definite individualistic sense of psychological self, but this self is strongly conditioned by group-oriented social relations. The social relations similar to guanxi play an important role in early Japanese people's lives. For example, early Japanese culture showed hesitation to interact with foreigners as individuals; they usually preferred that all business dealings were done among friends. This Japanese phenomenon is termed Kankei or Toyama no Kusun (Larson and Kleiner 1992). Blat, "a key phenomenon" (Ledneva 1998) in Soviet Union and post-Soviet states, reflects that guanxi-like behavior exists in non-Confucian country too. Blat is defined as the system of informal contacts and personal networks that are used to obtain social resources under the rationing that characterized Soviet Russia (Kaurinkoski 2000), which is quite similar to guanxi. Ledneva (1998) holds that blat is a social adaptation to the former Soviet Unions bureaucratic and chronic shortage of consumer goods. It rests on favors typically at the public's expense, based on individuals' differential access to goods and services through status or work. Every Soviet citizen knows what blat can bring him or her: food, consumer goods, adequate health care, housing, household upkeep, theater tickets, employment, job transfer, job promotion, etc (Hsu 2005). If we move focus to Arab countries, we may see a similar mechanism known as wasta (Cunningham and Sarayrah 1994). Wasta may be used to resolve inter-personal or inter-organizational conflict, and can also be used to interfere social process to obtain a job, a government document, a tax reduction, or admission to a prestigious university. Although these phenomena are termed differently across countries, they all share characteristics of guanxi, a long-term, reciprocal and instrumental relationship. Why is there such a salient similarity between guanxi and blat, and more generally kankei, and wasta? The answer can be found in the similarities of early stage of these societies: closed distribution systems, political insecurity, prevalence of state property, and an absence of systemic legal system. However, under the pressure of globalization and a motive toward modernity, these states, along with other developing counties, experienced or are experiencing changes to their respective processes.

Facts verify that rationalization is indispensable for modernity which requires a rational system that is calculable and efficient, reduces uncertainty, increases predictability, and uses an increasing amount of nonhuman technologies. Although Weber does not believe 
in a universal path of progress for all civilizations, rationalization, more or less, happens in all over the world, especially in developing countries in the twentyfirst century. In the economic field, complex global economy, intensive competition, and the consciousness of democracy require the developing countries to reason out any "irrational" sentiments such as compassion, camaraderie, and concerns that impede the accumulation and calculation of profit. In the administrative sphere, dehumanized relationships among personnel, objective rules, and codes of conduct "force" people to minimize subjectivity, and produce consistent and predictable results. In the political sphere, the institutional apparatuses are specifically designed to be immune to outside influences and external forces which may result in guanxi behaviors (Gane 2002). These changes, on one hand, reduce bureaucrats' authority to circumvent the administration, on the other hand, dehumanize social relationships among personnel. Therefore it is not surprising to see that accompanying the rationalization has been a decline of magic and religion, and also dehumanitarian. It can be predicted that guanxi-like behavior (including equivalents of guanxi in other countries) that grew from the irrational features of the social system will be institutionalized in a gradually different systematic environment that is less accommodating to instrumental social connections. As a result, guanxi-like behaviors will lessen. Its significance in people's life will also wither away round the world. However, to what degree can we cleanse guanxi-like behaviors depends on many social factors. Or it is implausible to wipe out due to human nature.

\section{CONCLUSION}

Guanxi, a part of the "stock knowledge" of Chinese adults, plays an important role in their management of everyday life. Guanxi-building is the Chinese version of network building, a universal phenomenon across cultures. It is used, consciously or unconsciously, by Chinese as cultural strategy to mobilize social resources for survival and development in various spheres of social life. As a socio-cultural concept, guanxi is deeply embedded in the relation-centered code of Confucianism and has its own sensibility in constituting societal structure of Chinese society. Under the Confucian code and the specific institutional structure (centralization, absence of rational legal system, structural uncertainty), Chinese are institutionalized to cultivate guanxi. However, the postreform Chinese economic, legal, political and cultural changes directed by rationalization are institutionalizing
Chinese society in another direction after 1978. As a result, the scope of guanxi will be narrowed and circumscribed. By and by, Chinese people will be more likely to accept universalistic ethics instead of particularistic ethics (i.e. guanxi). Given the similar institutional structure, there are equivalents of guanxi in other countries. Under the external and internal pressures, these countries have had or are having a similar process of rationalization which confines guanxi-like behaviors in a limited space. Consequently, the significance of these guanxi-like processes will be declining. However, since guanxi is a social phenomenon, and human beings inevitably have emotions, interests and affections in social interactions, guanxi phenomenon won't be eradicated in China. This is also partly why there are relational exchange process, nepotism, and favoritism even in the current individualist Western societies.

\section{REFERENCES}

Altson, Jon P. 1989. "Wa, Guanxi, and Inhwa: Managerial Principles in Japan, China, and Korea." Business Horizons 32(2): 2631.

http://dx.doi.org/10.1016/S0007-6813(89)80007-2

Ambler, Tim. 1994. "Marketing's Third Paradigm: Guanxi." Business Strategy Review 5(4): 69-80. http://dx.doi.org/10.1111/j.1467-8616.1994.tb00084.x

Baldinger, Pam. 1998. Distribution of Goods in China: Regulatory Framework and Business Options. Washington, DC: USChina Business Council.

Beck, Ulrich and Elisabeth Beck-Gernsheim. 2002 Individualization: Institutionalized Individualism and its Social and Political Consequences, London and Thousand Oaks, CA: Sage Publications.

Bian, Yanjie. 1994. Work and Inequality in Urban China. Albany, NY: State University of New York Press.

Bian, Yanjie. 2002. "Institutional Holes and Job Mobility Processes: Guanxi Mechanisms in China's Emergent Labor Markets." Pp. 117-135 in Social connections in China, edited by T. Gold, D. Guthrie, and D. Wank. Cambridge: Cambridge University Press.

Boisot, Max and John Child. 1996. "From Fiefs to Clans and Network Capitalism: Explaining China's Emerging Economic Order." Administrative Science Quarterly 41: 600-628. http://dx.doi.org/10.2307/2393869

Brown, Donald E. 1991. Human Universals. Philadelphia: Temple University Press.

Brubaker, Rogers. 1984. The Limits of Rationality. London: George Allen and Unwin.

Butterfield, Fox. 1983. China: Alive in Bitter Sea. London: Coronet Books.

Chen, Jianfu. 2008. Chinese law: Context and Transformation. Boston: Martinus Nijhoff Publishers. http://dx.doi.org/10.1163/ej.9789004165045.i-772

Chen, Phillip. M. 1973. Law and Justice: The Legal System in China 2400 B.C. to 1960 A.D. New York: Dunellen Publishing Company.

Chen, Xiaoping and Chao C. Chen. 2004. "On the Intricacies of the Chinese Guanxi: A Process Model of Guanxi Development." Asia Pacific Journal of Management 21: 305-324. http://dx.doi.org/10.1023/B:APJM.0000036465.19102.d5 
Chang, Ha-joon and Peter Evans. Jan. 13-14, 2000. The Role of Institutions in Economic Change. Retrieved April 28, 2012 (http://www.econ.cam.ac.uk/faculty/chang/cande-pdf.pdf)

Ching, Julia. 1977. Confucianism and Christianity: A Comparative Study. Tokyo: Kodansha International.

Chiu, Chui-liang. 1995. Democratizing Oriental Despotism: China from 4 May 1919 to 4 June 1989 and Taiwan from 28 February 1947 to 28 June 1990. New York: St. Martin's Press.

Cohen, Jerome A., Edwards R. Randle, and Fu-Mei C. Chen. 1980. Essays on China's Legal Tradition. Princeton, N.J.: Princeton University Press.

Coleman, James. 1990. "Social Capital in the Creation of Human Capital." American Journal of Sociology 94: 95-120. http://dx.doi.org/10.1086/228943

Coleman, James. 1993. "The Rational Reconstruction of Society." American Sociological Review 58: 1-15. http://dx.doi.org/10.2307/2096213

Cunningham, Robert B. and Yasin K. Sarayrah. 1994. "Taming Wasta to Achieve Development." Arab Studies Quarterly 16(3): 29-41.

De Bary, William T. 1970. Individualism and Humanitarianism in Late Ming Thought. Pp. 145-247 in Self and Society in Ming Thought, edited by William De Bary. New York: Columbia University Press.

DeGlopper, Donald R. 1978. "Doing Business in Lukang." Pp.291320 in Studies in Chinese Society, edited by Arthur P. Wolf. Stanford University Press.

Delman, Jorgen and Xiaoqing Yin. (2008). "Individualisation and Politics in China: The Political Identity and Agency of Private Business People." European Journal of East Asian Studies 7(1): 39-73. http://dx.doi.org/10.1163/156805808X333910

Earley, Christopher P. 1997. Face, Harmony, and Social Structure: An Analysis of Organizational Behavior Across Cultures. New York, NY: Oxford University Press.

Erez, Miriam and Christopher P. Earley. 1993. Culture, Self-identity and Work. New York: Oxford University Press. http://dx.doi.org/10.1093/acprof:oso/9780195075809.001.000 1

Fallers, Lloyd A. 1965. Bantu Bureaucracy. Chicago: University of Chicago Press.

Fan, Ying. 2002. "Guanxi' Consequences: Personal Gains at Social Trust." Journal of Business Ethics 38:371-380. http://dx.doi.org/10.1023/A:1016021706308

Fei, Xiaotong. 1967. Xiang Tu Zhong Guo (Earthy China). Taipei: LuChou Press.

Foster, William A. 2000. The Diffusion of the Internet in China. Palo Alto: Center for International Studies and Cooperation, Stanford University.

Fried, Morton H. 1974. Fabric of Chinese Society: A Study of the Social Life of Chinese County Seat. New York: Octagon Books.

Gane, Nicholas. 2002. Max Weber and Postmodern Theory. New York: Palgrave. http://dx.doi.org/10.1057/9780230502512

Glassman, Ronald M. 1991. China in Transition: Communism, Capitalism, and Democracy. New York: Praeger.

Goffman, Erving. 1955. "On Face Work: An Analysis of Ritual Elements in Social Interactions." Psychiatry: Journal of the Study of Interpersonal Process I(8): 213-231.

Greaves, Jane and Peter Baldwin. 1994. Distribution in China: Getting Down to the Nuts and Bolts. Hong Kong: Economist Intelligence Unit.

Gu, Flora F., Kineta Hung, and David K. Tse 2008. "When Does Guanxi Matter? Issues of Capitalization and Its Dark Sides." Journal of Marketing 72: 12-28.

http://dx.doi.org/10.1509/jmkg.72.4.12
Guthrie, Douglas. 1998. "The Declining Significance of Guanxi in China's Economic Transition." The China Quarterly 154: 3162. http://dx.doi.org/10.1017/S0305741000002034

Hasen, Mette Halskov and Cuiming Pang. 2008. European Journal of East Asian Studies 7(1): 75-99. http://dx.doi.org/10.1163/156805808X333929

Harvie, Charles. 2000. Contemporary Developments and Issues in China's Economic Transition. New York: St. Martin's Press. http://dx.doi.org/10.1057/9780230597198

Holmgren, Jennifer. 1995. Marriage, Kinship, and Power in Northern China. Brookfield, VT: Variorum.

Hsu, Carolyn. L. 2005. "Capitalism without Contracts versus Capitalists without Capitalism: Comparing the Influence of Chinese Guanxi with Russian Blat on Marketization." Communist and Post-Communist Studies 38(3): 309- 327. http://dx.doi.org/10.1016/i.postcomstud.2005.06.003

Hu, Hsien-Chin. 1944. "The Chinese Concepts of Face." American Anthropologist, 46: 45-64. http://dx.doi.org/10.1525/aa.1944.46.1.02a00040

Huang, Yihui. 2002. "The Personal Influence Model and Gao Guanxi in Taiwan Chinese Public Relations." Public Relations Review 26(2): 219.

http://dx.doi.org/10.1016/S0363-8111(00)00042-4

Hui, C. Harry and Harry C. Triandis. 1986. "IndividualismCollectivism: A Study of Cross-Cultural Researchers." Journal of Cross-Cultural Psychology 17(2): 225-48. http://dx.doi.org/10.1177/0022002186017002006

Hutchings, Kate and David Weir. 2006. "Guanxi and Wasta: A Comparison." Thunderbird International Business Review 48(1): 141-156. http://dx.doi.org/10.1002/tie.20090

Hwang, Kwang-kuo. 1987. "Face and Favor: The Chinese Power Fame." American Journal of Sociology 92: 944-974. http://dx.doi.org/10.1086/228588

Inkeles, Alex and David H. Smith. 1974. Becoming Modem: Individual Change in Six Developing Countries. Harvard University Press, Cambridge, MA.

Jacobs, Bruce J. 1979. "A Preliminary Model of Particularistic Ties in Chinese Political Alliances: Kan-ching and Kuan-his in a Rural Taiwanese Township." China Quarterly 8: 237-273. http://dx.doi.org/10.1017/S0305741000040467

Jankowiak, William R. 1993. Sex, Death, and Hierarchy in a Chinese City: An Anthropological Account. New York: Columbia University Press.

Jensen, Lionel M. 1997. Manufacturing Confucianism: Chinese Traditions and Universal Civilization. Durham: Duke University Press.

Kaurinkoski, Kira. 2000. "Russia's Economy of Favors, Blat, Networking and Informal Exchange." Social Anthropology 7(3): 336-337.

Kim, Hyung I. 1981. Fundamental Legal Concepts of China and the West: A Comparative Study. Port Washington, NY: Kennikat Press.

King, Ambrose Y.C. 1991. "Kuan-hsi and Network Building: A Sociological Interpretation." Daedalus 120: 63-84.

King, Ambrose Y.C. 1993. The Chinese Society and Its Culture. Hong Kong: Oxford University Press.

Kipnis, Andrew B. 1995. “'Face': An Adaptable Discourse of Social Surfaces." Positions: East Asia Cultures Critique 3(1): 119148.

http://dx.doi.org/10.1215/10679847-3-1-119

Kipnis, Andrew B. 1996. "The Language of Gift: Managing Guanxi in a North China Village." Modern China 22(3): 285-314. http://dx.doi.org/10.1177/009770049602200302

Kipnis, Andrew B. 1997. Producing Guanxi, Sentiment, Self, and Subculture in a North China Village. Durham, NC: Duke University Press. 
Kundu, Amibath. 2000. Inequality, Mobility, and Urbanization: China and India. New Delhi: Indian Council of Social Science Research and Manak Publications.

Larson, Hope H. and Brian H. Kleiner. 1992. "Understanding and Managing Asian Employees." Equal opportunities international 11(20): 18-22. http://dx.doi.org/10.1108/eb010571

LeBaron, Dean and Carpenter Donna. 2002. Mao, Marx, and the Market: Capitalist Adventures in Russia and China. New York: John Wiley and Sons.

Ledneva, Alena V. 1998. Russia's economy of favours: blat, networking, and informal exchange. Cambridge, UK: University of Cambridge Press.

Lee, Don Y., and Philip L. Dawes. 2005. "Guanxi, Trust, and LongTerm Orientation in Chinese Business Markets." Journal of International Marketing 13(2): 28-56. http://dx.doi.org/10.1509/jimk.13.2.28.64860

Lee, Shiyong. 2010. "Economics of Guanxi as an Interpersonal Investment Game." Review of Development Economics 14(2): 333-342.

http://dx.doi.org/10.1111/j.1467-9361.2010.00556.x

Leung, T.K.P., Vincent C.S. Heung, and Y.H. Wong. 2008. "Cronyism: One Possible Consequence of Guanxi for an Insider: How to Obtain and Maintain it?" European Journal of Marketing 42(1/2): 23-34.

http://dx.doi.org/10.1108/03090560810840899

Leung, T. K. P., Y.H. Wong, and S.Wong. 1996. "A Study of Hong Kong Businessmen's Perceptions of the Role "Guanxi" in the People's Republic of China." Journal of Business Ethics 15: 749-758. http://dx.doi.org/10.1007/BF00381739

Li, Mei-Chih. 1993. "Analysis of Chinese Self-other Relations: A Fairness Judgment Perspective." Indigenous Psychological Research in Chinese Societies 1: 267-300.

Lin, Liang-Hung. 2010. "Cultural and Organizational Antecedents of Guanxi: The Chinese Cases." Journal of Business Ethics 99: 441-451. http://dx.doi.org/10.1007/s10551-010-0662-3

Lin, Jun and Steven X. Si. 2010. "Can Guanxi be a Problem? Contexts, Ties, and Some Unfavorable Consequences of Social Capital in China." Asia Pacific Journal of Management 27: $561-581$.

http://dx.doi.org/10.1007/s10490-010-9198-4

Liu, Shuang. 2003. "Cultures within Culture: Unity and Diversity of Two Generations of Employees in State- owned Enterprises." Human Relations 56(4): 387-417. http://dx.doi.org/10.1177/0018726703056004001

Lo, Tit Wing and Guoping Jiang. 2006. "Inequality, Crime and the Floating Population in China." Asian Journal of Criminology 1(2): 103-118. http://dx.doi.org/10.1007/s11417-006-9000-1

Luo, Yadong. 1997. "Guanxi and International Joint-Venture Performance in China: An Empirical Inquiry." Management International Review 37(1): 51-70.

Luo, Yadong. 2007. Guanxi and Business. Singapore: World Scientific Publishing Co.

Ma, Ringo. 2011. "Social Relations (Guanxi): A Chinese Approach to Interpersonal Communication." China Media Research 7(4): 25-33.

McNally, Christopher A. 2011. "China's Changing Guanxi Capitalism: Private Entrepreneurs between Leninist Control and Relentless Accumulation". Business and Politics 13(2): 1-28. http://dx.doi.org/10.2202/1469-3569.1339

Ministry of Justice, P. R. China. 2010. "Chinese Ministry of Justice Says Chinese Lawyers Have Reached 166,000." Xinhua Agency, China, Feb 25, 2010. Retrieved April 28, 2012 (Http://politics.people.com.cn/GB/1027/10979482.html)
Mintz, Sidney. W. 1961. Pratik: Haitian Personal Economic Relationship. Pp. 53-64 in Annals of the Symposium Patterns of Land Utilization and Other Papers. Seattle, WA: American Ethnological Society.

Morgan, Robert M. and Shelby D. Hunt. 1994. "The Commitment Trust Theory of Relationship Marketing." Journal of Marketing 58: 20-38. http://dx.doi.org/10.2307/1252308

Nee, Victor. 1992. "Organizational Dynamics of Market Transition: Hybrid Forms, Property Rights, and Mixed Economy in China." Administrative Science Quarterly 37: 1-27. http://dx.doi.org/10.2307/2393531

Parsons, Talcott. 1949. The Structure of Social Action. New York: Free Press.

Parsons, Talcott. (Trans.) 1958. Author's Introduction, in The Protestant Ethic and the Spirit of Capitalism. New York: Scribner's Press.

Putnam, Robert D. 1993. Making Democracy Work. Princeton, N.J.: Princeton University Press.

Pye, Lucian W. 1982. Chinese Commercial Negotiating Style. Cambridge: Oelgeschlager, Gunnand Hain Inc.

Pye, Lucian W. 1995. "Faction and the Politics of Guanxi: Paradox in Chinese Administrative and Political Behavior." China Journal 34: 35-53. http://dx.doi.org/10.2307/2950132

Ralston, D. A., D.J. Gustafson, R.H. Terpstra, and D.H. Holt. 1995. "Pre-post Tiananmen Square: Changing Values of Chinese Managers." Asian Pacific Journal of Management 12(1): 120. http://dx.doi.org/10.1007/BF01733968

Ren, Jianmin and Zhizhou Du. 2008. "Institutionalized Corruption: Power Overconcentration of the First-in-Command in China." Crime, Law and Social Change 49(1): 45-59. http://dx.doi.org/10.1007/s10611-007-9090-4

Rosement, Henry Jr. (1991). A Chinese mirror. La Selle, IL: Open Court.

Rodrik, Dani. 2000. Development Strategies for the Next Century. Pp. 1-38 in Proceeding of the Conference on Developing Economics in the 21st Century. Japan: Institute for Developing Economics.

Ruehle, Susanne. 2010. "Guanxi as competitive advantage during economic crises: Evidence from China during the recent global financial crisis". Paper presented at the 21st CEA (UK) and 2nd CEA (Europe) Annual Conference, July 12-13, Oxford, UK: University of Oxford.

Schelle, Orville. 1989. Discos and Democracy: China in the Throes of Reform. New York: Anchor Books.

Skinner, Burrhus F. 1977. "Between Freedom and Despotism." Psychology Today 11:80-82, 84, 86, and 90-91.

Sik, Endre. 1994. Network Capital in Capitalist, Communist and Postcommunist Countries. Pp.225-254 in Networks in the Global Village, edited by W. Barry. Boulder, Co.: Westview Press.

Silin, Robert H. 1970. Leadership and Values. Cambridge: Harvard University Press.

Smart, Alan. 1993. "Gift, Bribes and Guanxi: A Reconsideration of Bourdieu's Social Capital." Cultural Anthropology 8(3): 388408. http://dx.doi.org/10.1525/can.1993.8.3.02a00060

State Council Information Office, China. 2011. The Socialist System of Laws with Chinese Characteristics, the White Paper.

Stiglitz, Joseph E. and Gerald M. Meier. eds. 2000. Frontiers of Development Economics. New York: Oxford University Press \& World Bank

Su, Chenting, Ronald K. Mitchell and Joseph M. Sirgy. 2007. "Enabling Guanxi Management in China: A Hierarchical Stakeholder Model of Effective Guanxi." Journal of Business Ethics 71: 301-319.

http://dx.doi.org/10.1007/s10551-006-9140-3 
Tsang, Eric W.K. 1998. "Can Guanxi be a Source of Sustained Competitive Advantages for Doing Business in China?" The Academy of Management Executive 12(2): 64-73.

Tsui, Anne S. and Jiing-Lih K. Farh. 1997. "Where Guanxi Matters: Relational Demography and Guanxi in the Chinese Context." Work and Occupations 24(10): 56-79. http://dx.doi.org/10.1177/0730888497024001005

Triandis, Harry C. 1995. Individualism and Collectivism. Boulder: Westview Press.

Turner, Karen G., James V. Feinerman, and Kent R. Guy. 2000. The Limits of the Rule of Law in China. Seattle: University of Washington Press.

Vogel, Ezra. 1965. "From Friendship to Comradeship: The Change in Personal Relations in Communist China." The China Quarterly 21:46-60.

Walder, Andrew. G. 1986. Communist Neo-traditionalism. Berkeley: University of California Press.

Wang, Qi. 1996. Job Change in Urban China: An Assessment of Socialist Employment Relationship. New York: Peter Lang Publication Inc.

Wank, David L. 2001. Commodifying Communism: Business, Trust, and Politics in a Chinese City. New York: Cambridge University Press.

Weakland, John H. 1950. "The Organization of Action in Chinese Culture." Psychiatry 13:361-370.

Weber, Max. 1978. Economy and Society: An Outline of Interpretive Sociology, edited by G Roth and C. Wittich, translated by E. Fischoff et al. Berkeley: University of California Press.

Weber, Max. 1997. The Protestant Ethic and the Spirit of Capitalism. London: Routledge.

Wellman, Barry and Scott Wortley. 1989. "Brothers Keepers: Situating Kinship Relations in Broader Networks of Social Support." Sociological Perspectives, 32:273-306. http://dx.doi.org/10.2307/1389119

Whiting, Susan H. 2001. Power and Wealth in Rural China: the Political Economy of Institutional Change. New York: Cambridge University Press.

Wong, Mei-ling. 2010. "Guanxi Management as Complex Adaptive Systems: A Case Study of Taiwanese ODI in China." Journal of Business Ethics 91:419-432. http://dx.doi.org/10.1007/s10551-009-0093-1

Wong, Siu-lun. Feb. 1997. Trust and Prosperity: The Role of Chinese Family Enterprises in Economic Development. In Tsui, T.T.'s lecture at the Australian National University on February 1-5, 1997.
Woo, Wing Thye. 1999. The Economics and Politics of Transition to an Open Market Economy: China. Paris, France: Development Centre, Organization for Economic Cooperation and Development. http://dx.doi.org/10.1787/322178001745

Xin, Catherine R. and Jone L. Pearce. 1996. "Guanxi: Connections as Substitutes for Formal Institutional Support." Academy of Management Journal 39(6): 1641-1658. http://dx.doi.org/10.2307/257072

Yan, Yunxiang. 1996. The Flow of Gifts: Reciprocity and Social Networks in a Chinese Village. Stanford, California: Stanford University Press.

Yan, Yunxiang. 2010. "The Chinese Path to Individualization." The British Journal of Sociology 61(3): 489-512. http://dx.doi.org/10.1111/j.1468-4446.2010.01323.x

Yang, His-pao. 1955. Fact-Finding with Rural People: A Guide to Effective Social Survey. Rome: Food and Agriculture Organization of the United Nations.

Yang, Liensheng. 1957. The Concept of Pao as Basis for Social Relations in China. Pp. 291-309 in Chinese Thought and Institutions, edited by J. K., Fairbank. Chicago: University of Chicago Press.

Yang, Kuo-shu. 1981. "Social Orientation and Individual Modernity among Chinese Students in Taiwan." The Journal of social psychology 113: 159-170. http://dx.doi.org/10.1080/00224545.1981.9924368

Yang, Kuo-shu. 1986. Chinese Personality and Its Change. Pp. 106160 in The Psychology of Chinese People, edited by M.M. Bond. Hong Kong: Oxford University Press.

Yang, Kuo-shu. 1988. Will Societal Modernization Eventually Eliminate Cross-Cultural Challenge Difference? Pp.67-85 in The Cross Cultural Challenge to Social Psychology, edited by M.M. Bond. London, UK: Sage publications.

Yang, Mayfair M.H. 1994. Gifts, Favors and Banquets: the Art of Social Relationship in China. New York: Cornell University Press.

Yeung, Irene. Y. M. and Rosalie L. Tung. 1996. "Achieving Business Success in Confucian Societies: the Importance of Guanxi." Organizational Dynamics, 25(2): 54-65. http://dx.doi.org/10.1016/S0090-2616(96)90025-X

Zhao, Xiangyang. 2005. "Guanxi (Special Personal Connections) and Business Success in China". Chinese Public Affairs Quarterly 1(3): 211-223.

\section{DOl: http://dx.doi.org/10.6000/1929-4409.2012.01.19}

(C) 2012 Jiang et al.; Licensee Lifescience Global.

This is an open access article licensed under the terms of the Creative Commons Attribution Non-Commercial License (http://creativecommons.org/licenses/by-nc/3.0/) which permits unrestricted, non-commercial use, distribution and reproduction in any medium, provided the work is properly cited. 